\title{
Skrining Efektivitas Ekstrak Tanaman Herbal sebagai Anthelmintik terhadap Telur dan Lana Nematoda serta Cacing Haemonchus contortus sec ara In-Vitro
}

\section{(Sc reening Effec tiveness of Herbs Extracts as Anthelmintic Against Eggs, Larvae of Nematode and Haemonc hus contortus Adult Worms In-Vitro)}

\author{
Ekawasti $\mathrm{F}^{1}$, Suhardono ${ }^{1}$, Dewi DA. ${ }^{2}$, Martindah $\mathrm{E}^{1}$, Wardhana $\mathrm{AH}^{1}$, Sawitri $\mathrm{DH}^{1}$ \\ ${ }^{1}$ Balai Besar Penelitian Veteriner, R.E. Martadinata No. 30 Bogor \\ ${ }^{2}$ Politeknik Pembangunan Pertanian Yogyakarta, Magelang \\ fitrineekawasti@gmail.com
}

\begin{abstract}
Hemonchosis is caused by the nematode of Haemonchus contortus, which can cause high economic losses. The most common treatment for helminthiasis is by broad-spectrum chemical anthelmintics, but if used continuously for a long time can cause resistance and residue to livestock products, which pose a serious threat to livestock production. This study aims to conduct screening tests on herbal plants that can be used as effective and efficient nematode worm medicines. Bitter melon seeds (Momordica charantia L.), white ginger (Curcuma zedoaria Rosce), noni fruit (Morinda citrifolia), cassava leaves (Manihot uttilissima), avocado seeds (Persea americana Mill), papaya leaves (Carica papaya L.), katuk leaves (Sauropus androgynus L. Merr), areca nut (Areca catechu), garlic (Allium sativum) and gum gambier (Uncaria gambier Roxb) were extracted and tested for phytochemistry at the Spice and Drug Research Institute (Balittro). Screening tests were carried out using 10 herbal plant extracts against eggs, larvae of nematode and $H$. contortus adult worms using $1 \%$ DMSO media in vitro. The results showed that sequentially 5 herbs of avocado seeds, white Intersection, momordica seeds, noni fruit and areca nut potential as nematode worm medicines in ruminants were effective and efficient.
\end{abstract}

Key words: Haemonchus contortus, herbs, nematodes, worming, digestive tract

\begin{abstract}
ABSTRAK
Hemonchosis disebabkan oleh cacing nematoda Haemonchus contortus dan dapat menyebabkan kerugian ekonomi yang tinggi. Penanganan dan pengendalian kecacingan yang paling umum dilakukan adalah dengan pemberian anthelmintika kimia berspektrum luas, tetapi jika digunakan secara terus menerus dalam waktu yang lama dapat mengakibatkan resistensi dan residu terhadap produk ternak yang menjadi ancaman serius bagi produksi ternak. Penelitian ini bertujuan untuk melakukan uji skrining terhadap tanaman herbal yang dapat digunakan sebagai obat cacing nematoda yang efektif dan efisien. Biji pare (Momordica charantia L.), temu putih (Curcuma zedoaria Rosce), buah mengkudu (Morinda citrifolia), daun singkong (Manihot uttilissima), biji alpukat (Persea americana Mill), daun pepaya (Carica papaya L.), daun katuk (Sauropus androgynus L. Merr), buah pinang (Areca catechu), bawang putih (Allium sativum) dan getah gambir (Uncaria gambir Roxb) diperoleh, diekstrak dan diuji fitokimia di Balai Penelitian Rempah dan Obat (Balittro). Uji skrining dilakukan dengan menggunakan 10 ekstrak tanaman herbal terhadap telur dan larva nematoda serta cacing dewasa $H$. contortus menggunakan media DMSO 1\% secara in vitro. Hasil penelitian menunjukkan bahwa secara berurutan 5 tanaman obat alami biji alpukat, rimpang
\end{abstract}


temu putih, buah mengkudu dan buah pinang berpotensi sebagai obat cacing nematoda pada ruminansia biji pare, yang efektif dan efisien.

Kata kunci: Haemonchus contortus, herbal, nematoda, obat cacing, saluran pencernaan

\section{PENDAHULUAN}

Infestasi parasit oleh Haemonchus contortus umumnya merupakan masalah kesehatan pada ternak dengan prevalensi tinggi di dunia yang menyebabkan penurunan produksi secara signifikan dan merupakan kasus yang sering terjadi di Indonesia (Beriajaya 2005). Penyakit ini disebabkan oleh cacing gilik/kelas Nemotoda (Dzulzila \& Izranuddin 2004; Jabbar et al. 2013). Walaupun nematodosis tidak langsung menyebabkan kematian, namun secara ekonomi dapat menimbulkan kerugian yang sangat besar. Oleh karena itu penyakit ini sering disebut sebagai penyakit ekonomi. Kerugian akibat infeksi cacing sulit diperkirakan, biasanya berupa kematian pada derajat infeksi tinggi terutama pada ternak muda, rendahnya produksi susu, keterlambatan pertumbuhan, rendahnya pertambahan berat badan dan penurunan daya tahan tubuh akibat anemia yang ditimbulkan, serta penurunan kekuatan tenaga kerja ternak (Mitchell 2007; Siregar 2013). Populasi ternak sapi di Indonesia cukup besar dan kerugian yang ditimbulkan akan terus meningkat bila masalah nematodosis tidak dikendalikan (Jackson et al. 2009; Papadopoulos et al. 2012).

Program pencegahan dan pengendalian nematodiasis pada ternak dilakukan melalui penggunaan obat cacing (anthelmentik) spektrum luas seperti kelompok benzimidazole (BZ), levamisole (LEV) atau ivermectin (IVM). Penggunaan anthelmintik saat ini, telah banyak dilaporkan kejadian resistensi cacing nematoda terhadap anthelmintik di beberapa negara yang semakin meningkat (Papadopoulos 2008; Papadopoulos et al. 2012; Nabukenya et al. 2014) termasuk Indonesia (Haryuningtyas et al. 2001). Meningkatnya kejadian resistensi obat cacing nematoda gastrointestinal dan timbulnya residu obat dalam tubuh hewan dapat menjadi ancaman yang serius bagi produksi ternak (Prichard 2001; Kaplan 2004; Kumara et al. 2010). Tingginya persentase larva H. contortus dibandingkan dengan larva cacing lain dapat membahayakan produktivitas ternak sehingga perlu strategi pengendalian yang tepat terhadap hemonchosis (Dewi et al. 2017)

Salah satu alternatif penanggulangan terhadap hemonchosis ialah dengan pengembangan bahan obat dari alam. Saat ini sudah banyak ditemukan khasiat farmakoseutika dari berbagai tanaman yang dapat dimanfaatkan untuk penanganan masalah kesehatan ternak khususnya kecacingan yang disebabkan oleh $H$. contortus (Ardana 2012). Berdasarkan beberapa laporan, bahan obat dari alam yang dapat digunakan sebagai anthelmintik, diantaranya sebagai berikut: Biji pare (Momordica charantia L.), temu putih (Curcuma zedoaria Rosce), buah mengkudu yang sudah matang (Morinda citrifolia), daun singkong (Manihot uttilissima), biji alpukat (Persea americana mill), daun pepaya (Carica papaya L.), daun katuk (Sauropus androgynus L. Merr), buah pinang yang berwarna kuning kemerahan (Areca catechu), bawang putih dan getah gambir (Uncaria gambir Roxb). Tanaman tersebut banyak terdapat di lingkungan masyarakat sehingga mudah untuk diperoleh, tetapi belum diketahui manfaat optimalnya sebagai obat cacing.

Beberapa mekanisme kerja anthelmintik dalam memberantas cacing adalah membunuh larva (larvasidal), cacing dewasa (vermisidal), serta dapat menghambat perkembangan telur cacing (ovisidal) (Ardana 2012). Perlu dilakukan penelitian untuk mengetahui jenis tanaman herbal yang paling efektif dan efisien yang dapat digunakan sebagai obat cacing nematoda, baik yang dapat digunakan sebagai ovisidal, larvasidal 
maupun vermisidal dengan memutus siklus hidup atau sebagai pengobatan terhadap infeksi cacing.

\section{MATERI DAN METODE}

\section{Hewan donor}

Hewan donor yang digunakan adalah domba 3 ekor, jantan, umur \pm 8 bulan dan berat badan sekitar 13-15 kg. Domba dipelihara secara intensif di dalam kandang yang terjaga kebersihannya. Pakan diberikan berupa konsentrat, sedangkan minumannya adalah air minum yang diberikan secara ad libitum.

Domba berada dalam kondisi klinis sehat dan dibebaskan dari infeksi cacing nematoda intestinal, kemudian diinfestasi dengan larva nematoda Haemonchus contortus (Balitbangtan/BB Litvet/Rm_NRm/07.01/2017).

\section{Infestasi larva cacing pada hewan donor}

Larva cacing nematoda hasil kultur dari sampel feses diinfestasikan kepada hewan donor agar dapat memproduksi jumlah telur nematoda dan cacing dewasa Haemonchus contortus sesuai kebutuhan.

Infestasi larva dilakukan pada domba donor secara berulang dengan interval 10 hari dengan dosis bertingkat sebanyak 5000, 10.000, dan 15.000 larva. Pemeriksaan dengan penghitungan Egg per gram (EPG) tinja dilakukan pada minggu ke 3-4 PI. Infeksi ulang dihentikan bila dari penghitungan EPG sudah mencukupi kebutuhan untuk penelitian pada uji in vitro.

\section{Sampel feses}

Pengambilan feses domba donor diambil secara pull (digabung dari 3 ekor domba). Sampel feses yang telah diperoleh dimasukkan ke dalam kantong plastik diikat sedemikian rupa sehingga tidak mengandung udara dan diberi label kemudian dimasukkan ke dalam termos es pada suhu $4^{\circ} \mathrm{C}$ dan dibawa ke laboratorium.

\section{Purifikasi telur dari sampel feses}

Penghitungan jumlah telur cacing per gram feses dengan metode Whitlock (Whitlock 1948), bila jumlah telur cacing cukup banyak (epg > 100) maka dilanjutkan dengan penyaringan menggunakan saringan ukuran 250 dan $180 \mu \mathrm{m}$. Untuk memisahkan telur dari kotoran digunakan gradien gula dengan konsentrasi 10\% (kuning), 25\% (Biru) dan 40\% (pink) kemudian disentrifus pada $3000 \mathrm{rpm}$ selama 10 menit. Setelah disentrifus, telur nematoda akan terletak diantara lapisan kuning dan biru. Dengan menggunakan pipet pasteur telur dikoleksi dan ditempatkan pada saringan $25 \mu \mathrm{m}$. Telur dibersihkan dari larutan gula dan dikoleksi dalam tabung sentrifus $15 \mathrm{~mL}$.

\section{Kultur larva cacing Nematoda}

Sampel positif yang mengandung telur nematoda disiapkan untuk membuat pupukan telur cacing (kultur larva). Kultur larva dilakukan untuk mendapatkan $\mathrm{L}_{3}$ dalam jumlah banyak. Media kultur larva yang terbuat dari campuran feses (5 gram) dan media vermiculite (media tanam pengeraman telur) dengan perbandingan 1:1 diberi air 
secukupnya agar lembab tetapi tidak basah kemudian disimpan pada suhu kamar dan tidak kena sinar matahari langsung selama 7-9 hari.

Larva cacing hasil kultur diidentifikasi secara mikroskopik. Identifikasi larva dilakukan berdasarkan pedoman Manual MAFF (Georgi \& Theodorides 1980). Larva hasil kultur disimpan dalam lemari pendingin $\left(4^{\circ} \mathrm{C}\right)$.

\section{Preparasi cacing Haemonchus contortus}

Cacing dewasa $H$. contortus diperoleh dengan cara memotong domba donor pada minggu kedelapan setelah dihitung EPG cukup sesuai kebutuhan untuk mendapatkan cacing $H$. contortus. Bagian abomasum disayat pada sisi curvatura mayor, kemudian dicuci menggunakan air dan disaring dengan saringan 350 mikro dan 250 mikro selanjutnya hasil saringan (filtrate) ditampung di dalam nampan. Cacing dikoleksi dengan menggunakan pinset/sonde untuk mempermudah dalam mengambil cacing yang terlihat. Cacing $H$. contortus yang diperoleh dikumpulkan di dalam cawan yang berisi $\mathrm{NaCl}$ fisiologis dan segera digunakan untuk uji.

\section{Ekstrak tanaman herbal}

Biji pare (Momordica charantia L.), temu putih (Curcuma zedoaria Rosce), buah mengkuduyang sudah matang (Morinda citrifolia), daun singkong (Manihot uttilissima), Biji Alpukat (Persea americana Mill), daun pepaya (Carica papaya L.), daun katuk (Sauropus androgynus L. Merr), buah pinang yang berwarna kuning kemerahan (Areca catechu), bawang putih dan getah gambir (Uncaria gambir Roxb) diperoleh dari waktu dan lokasi yang sama dan sekaligus diekstraksi di Balai Penelitian Rempah dan Obat (Balittro). Bahan obat alami tersebut diekstrak dengan metode maserasi menggunakan pelarut ethanol 96\% (Nuri 2007).

\section{Penapisan fitokimia}

Setiap sampel ekstrak tanaman herbal diuji fitokimia terhadap adanya golongan senyawa alkoloid, flavonoid, antrakuinon, steroid/titerpenoid, saponin dan tanin menggunakan metode yang sudah baku (Ridwan \& Ayunita 2007; Tiuria \& Retnani 1991).

\section{Uji skrining aktivitas ekstrak tanaman herbal sebagai anthelmintik terhadap telur dan larva Nematoda serta cacing $H$. contortus secara in vitro}

\section{Uji aktivitas anthelmintik terhadap daya tetas telur}

Telur cacing nematoda hasil purifikasi dimasukan ke dalam cawan petri d $5 \mathrm{~cm}$ yang telah berisi ekstrak etanol 96\% beberapa tanaman herbal dengan konsentrasi 1\%. Kontrol negatif menggunakan media pelarut yang baik terhadap telur nematoda (Ekawasti et al. 2017) dan kontrol positif menggunakan anthelmintik yang sering dipakai di lapangan dan sesuai dosis yang telah ditentukan pada etiket obat (albendazole). Setiap cawan petri diisi \pm 200 telur cacing nematoda dalam larutan ekstrak herbal dan dimetil sulfoksida (DMSO) 1\%, kemudian diinkubasi selama 24 jam. Pengamatan dan penghitungan dilakukan terhadap daya tetas telur. Pengujian ini dilakukan dengan 3 kali ulangan. 


\section{Uji aktivitas anthelmintik terhadap mortalitas larva}

Setiap cawan petri diisi \pm 200 larva cacing nematoda dalam larutan ekstrak herbal. Pengamatan dilakukan terhadap jumlah larva cacing yang mati dengan lama waktu pengamatan selama 40 jam (Agung 2012). Pada penelitian ini dilakukan pengamatan selama 24 jam dan 48 jam dan dilakukan dengan 3 kali ulangan.

\section{Uji aktivitas anthelmintik terhadap mortalitas $\boldsymbol{H}$. contortus}

Setiap cawan petri diisi 5 ekor cacing dewasa dalam larutan ekstrak herbal. Parameter yang diukur untuk uji in vitro terhadap cacing dewasa adalah persentase kematian cacing dewasa akibat pemberian ekstrak obat cacing pada pengamatan setiap 24 jam selama 6 jam sampai semua cacing mati (Lismayanti 2002). Dilakukan pengamatan tiap jam hingga jam ke- 6 dibawah mikroskop stereo.

\section{Analisis data}

Data yang diperoleh dari hasil pemeriksaan laboratorium ditabulasikan menggunakan program Microsoft Excel dan dianalisa sacara deskriptif.

\section{HASIL DAN PEMBAHASAN}

\section{Ekstrak etanol 96\% tanaman herbal}

Tanaman herbal (bahan obat alami) yang diekstrak adalah biji pare (Momordica charantia L.), temu putih (Curcuma zedoaria Rosce), buah mengkudu (Morinda citrifolia), daun singkong (Manihot uttilissima), biji alpukat (Persea americana Mill), daun pepaya (Carica papaya L.), daun katuk (Sauropus androgynus L. Merr), buah pinang (Areca catechu), bawang putih (Alium sativum L) dan getah gambir (Uncaria gambir Rox). Dipilih 10 tanaman herbal berdasarkan studi literatur memiliki potensi sebagai anthelmintik dan karena tanaman tersebut mudah diperoleh serta pemanfaatannya sebagai obat cacing belum optimal, sehingga diharapkan dengan hasil penelitian ini menjadikan bahan obat alami tersebut lebih bermanfaat secara optimal. Menurut Ahmad (2014) pemberian obat alami yang mengandung anthelmintik dapat menurunkan derajat infeksi kecacingan dan lebih murah dari harga obat pabrik.

Ekstraksi tanaman dilakukan dengan metode maserasi, metode ini dipilih dengan tujuan menghindari rusaknya komponen senyawa akibat panas. Proses maserasi dilakukan berulang sebanyak tiga kali dengan tujuan memperoleh hasil ekstraksi yang maksimal dan menghindari adanya zat aktif yang belum terekstraksi pada maserasi pertama (Basir 2013). Pelarut yang digunakan adalah etanol 96\%, karena etanol 96\% lebih mudah diuapkan, tidak bersifat toksik, serta dapat mengekstraksi bahan kering, daun-daunan, batang, biji dan akar (Munawaroh \& Handayani 2010).

Etanol merupakan pelarut universal sehingga dapat menghasilkan ekstrak dengan jumlah rendemen yang lebih banyak dibandingkan pelarut air maupun pelarut organik lainnya. Etanol mampu melarutkan hampir semua zat baik yang bersifat polar, semi polar, dan non polar serta kemampuannya untuk menghambat kerja enzim yang dapat menghidrolisis dan mengoksidasi metabolit yang terekstraksi (Voight 1995). Ekstrak etanol memiliki kemampuan signifikan daripada ekstrak air dalam menekan jumlah telur nematoda usus (Razali et al 2014; Fabriana et al. 2010). 


\section{Penapisan fitokimia tanaman herbal}

Potensi tanaman herbal anti nematoda diperkirakan berasal dari kelompok cysteine proteinases yang dapat merusak nematoda intestinal (Buttle et al. 2011; Jeyathilakan et al. 2011; Njoku \& Obi 2009).

Uji fitokimia kualitatif dilakukan untuk mengetahui kandungan senyawa aktif pada ekstrak obat alami yang dapat digunakan sebagai anthelmintik (Ridwan \& Ayunita 2007). Penapisan senyawa fitokimia dapat menentukan kandungan metabolit sekunder untuk menentukan senyawa aktif yang berpotensi sebagai anthelmintik (Tabel 1).

Hasil penapisan fitokimia pada ekstrak tanaman obat alami menunjukkan adanya senyawa metabolit sekunder alkaloid, flavonoid, saponin, steroid, triterpenoid dan tanin pada sampel ekstrak tanaman herbal yang merupakan senyawa anthelmintik. Senyawa metabolit sekunder tanaman seperti alkaloid, flavonoid, tannin, steroid dan saponin memiliki aktivitas antelmintik (Hrckova \& Velebny 2013; Sarojini et al. 2012; Kamaraj et al. 2011). Berbagai hasil penelitian menunjukkan bahwa adanya senyawa-senyawa tersebut dapat membunuh larva. Unsur flavonoid, saponin dan stroid adalah unsur yang tidak disukai oleh parasit (Surya 2014).

Tabel 1. Hasil uji fitokimia ekstrak tanaman herbal etanol 96\%

\begin{tabular}{lcccccc}
\hline \hline \multirow{2}{*}{ Sampel } & \multicolumn{7}{c}{ Skrining fitokimia } \\
\cline { 2 - 7 } & Alkaloid & Flavonoid & Saponin & Steroid & Triterpenoid & Tanin \\
\hline Daun pepaya & + & + & - & - & - & + \\
Daun singkong & + & + & + & - & - & + \\
Daun katuk & + & + & + & - & + & + \\
Buah pinang & + & + & + & - & + & + \\
Bawang putih & + & + & + & - & + & + \\
Mengkudu & + & + & + & + & + & - \\
Temu putih & + & + & + & - & - & + \\
Biji alpukat & + & - & + & - & + & + \\
Biji pare & + & - & + & - & + & + \\
Getah gambir & + & + & + & - & + & + \\
\hline
\end{tabular}

Keterangan: (+) : terdapat senyawa (-) tidak terdapat senyawa

\section{Aktivitas anthelmintik ekstrak tanaman herbal terhadap telur dan larva Nematoda serta cacing $H$. contortus secara in vitro}

Sepuluh jenis tanaman obat alami sebagai ekstrak herbal etanol 96\% dari biji pare (Momordica charantia L.), temu putih (Curcuma zedoaria Rosce), buah mengkudu (Morinda citrifolia), daun singkong (Manihot uttilissima), biji Alpukat (Persea americana Mill), daun pepaya (Carica papaya L.), daun katuk (Sauropus androgynus L. Merr), buah pinang (Areca catechu), bawang putih (Alium sativum L) dan getah gambir (Uncaria gambir Rox). Pelarut yang digunakan untuk melarutkan ekstrak etanol tanaman herbal yang kemudian akan dicampur dengan telur cacing nematoda untuk uji in vitro adalah DMSO 1\% (Ekawasti et al. 2017). 
Pengamatan dilakukan selama 24 jam dalam keadaan inkubasi telur berada dalam larutan ekstrak herbal. Menurut Beriajaya et al. (2006) waktu inkubasi telur cacing untuk menghitung telur cacing yang menetas dapat dilakukan setelah 48 jam pada suhu kamar. Uji in vitro terhadap telur cacing adalah persentase telur cacing yang menetas selama 48 jam (Manurung \& Beriajaya 2004). Hal ini menyatakan bahwa telur cacing dapat bertahan hingga 48 jam di suhu ruang dalam keadaan baik. Pemilihan waktu pengamatan pada jam ke-24 dapat mempercepat waktu dan mendapatkan hasil yang optimal karena dalam keadaan normal kondisi telur pada jam ke-24 masih baik (Ekawasti et al. 2017).

Ada beberapa faktor yang mempengaruhi tingkat resistensi anthelmintik untuk cacing nematoda salah satunya adalah variasi prolifikasi (pelepasan telur) pada masingmasing spesies. Haemonchus contortus merupakan spesies cacing yang sangat produktif (5.000-10.000 telur/cacing betina/hari) (Garduno 2013; Emery 2016). Anthelmintik tidak mampu secara optimal menghambat proses pelepasan telur dikarenakan tingginya tingkat produktivitas dari cacing Haemonchus spp. ini. Sehingga perlu diketahui obat cacing yang dapat mempengaruhi kualitas telur cacing/menghambat daya tetas telur.

Hasil uji skrining awal secara in vitro untuk mengetahui potensi tanaman herbal terhadap daya tetas telur cacing nematoda pada pengamatan selama 24 jam (Gambar 1.). Parameter pengamatan daya tetas telur dapat dilihat dari telur yang tidak menetas atau telur yang menetas tapi larva mati dalam waktu 24 jam. Larva lemah atau cepat mati yang dihasilkan oleh telur yang telah terpapar oleh ekstrak herbal berarti menunjukkan bahwa kualitas telur cacing tersebut buruk (embrio lemah). Ekstrak tanaman herbal yang dapat menurunkan daya tetas telur merupakan salah satu parameter yang dapat digunakan untuk menentukan kandidat tanaman herbal yang berpotensi sebagai obat cacing (ovisidal).

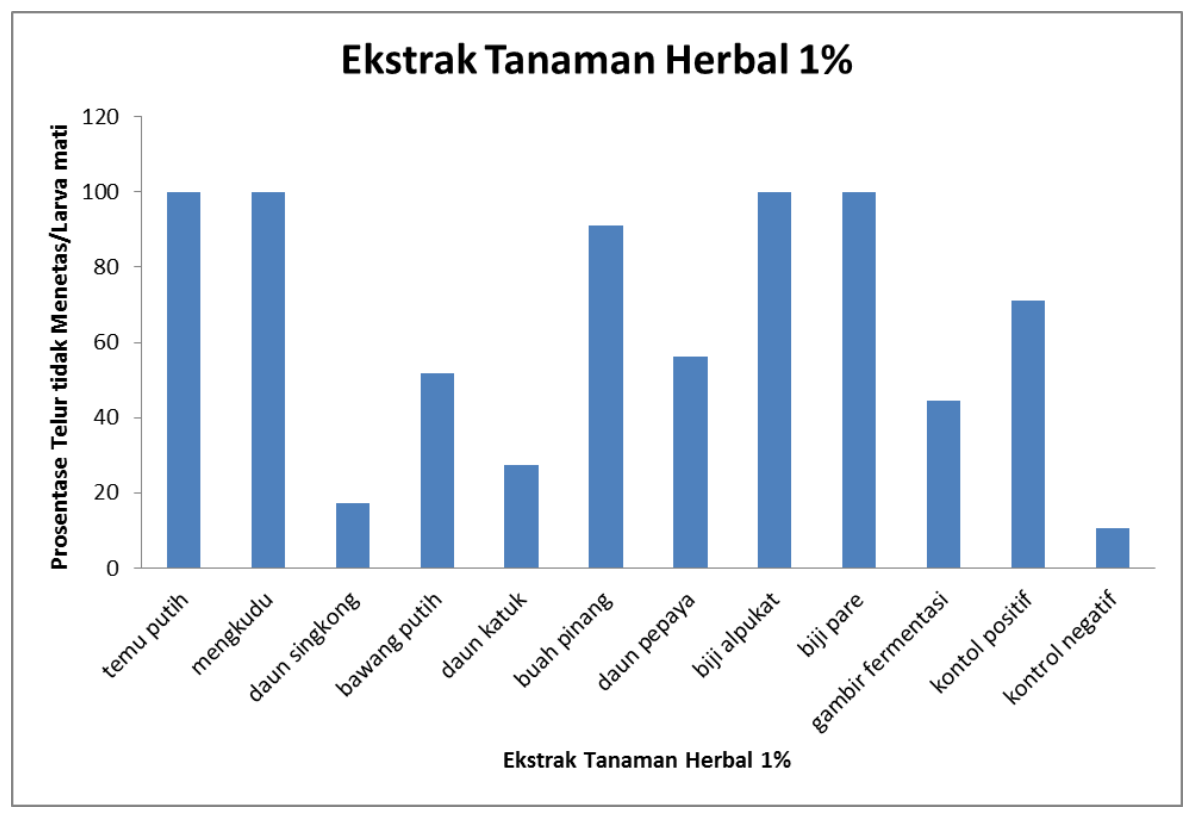

Keterangan:

Kontrol positif: Albendazole

Kontrol negatif: DMSO 1\%

Gambar 1.Hasil uji skrining 10 ekstrak tanaman herbal 1\% + DMSO 1\% pada telur nematoda selama 24 jam 
Obat cacing yang dapat menghambat daya tetas telur berarti dapat memutus rangkaian siklus hidup nematoda sehingga larva yang menetas tidak dapat berkembang menjadi larva infektif yang dapat menginfeksi ternak. Diantara 10 ekstrak etanol 96\% tanaman herbal tersebut secara berurut yang memiliki potensi sebagai obat cacing yang bersifat ovisidal yaitu temu putih, mengkudu, biji alpukat, biji pare dan buah pinang.

Hasil uji skrining awal secara in vitro untuk mengetahui potensi tanaman herbal terhadap mortalitas (daya hidup) larva cacing nematoda pada pengamatan selama 24 jam (Tabel 2.). Pengamatan terdap uji skrining ekstrak herbal terhadap mortalitas larva dilakukan pada jam ke-24 dan ke-48. Menurut Agung (2012) pengamatan dilakukan terhadap jumlah larva cacing yang mati/lemah dengan lama waktu pengamatan selama 40 jam. Berdasarkan hasil pengamatan ekstrak tanaman herbal yang memiliki potensi (persentasi tinggi) dalam membunuh larva (larvasidal) baik pada jam ke-24 maupun jam ke-48, yaitu ekstrak biji pare, biji alpukat, mengkudu, pinang, temu putih.

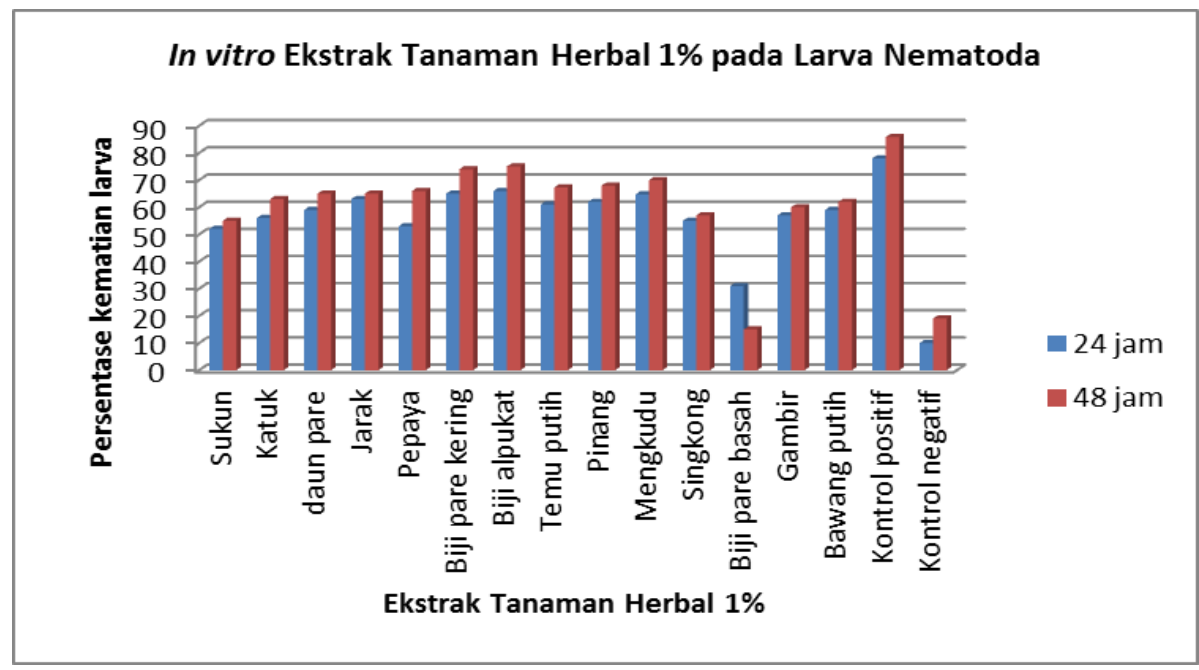

\section{Keterangan:}

Kontrol positif: Albendazole

Kontrol negatif: DMSO 1\%

Gambar 2. Hasil uji skrining 10 ekstrak tanaman herbal 1\% pada larva nematoda

Mekanisme obat cacing secara larvasidal dapat dijadikan parameter dalam pemilihan obat cacing yang bersifat kontrol biologis pada lingkungan. Larva nematoda menetas di lingkungan sehingga jika rantai siklus hidupnya diputus di lingkungan maka fungsi obat tersebut dapat juga digunakan sebagai kontrol biologis terhadap cacing nematoda. Hasil uji skrining awal secara in vitro untuk mengetahui potensi tanaman herbal terhadap mortalitas (daya hidup) larva cacing nematoda pada pengamatan selama 24 jam (Gambar 3).

Uji skrining efektivitas ekstrak obat herbal terhadap mortalitas cacing dewasa $H$. contortus dilakukan secara in vitro menggunakan cacing hasil panen dari donor yang telah diketahui status resistensinya. Parameter yang diukur untuk uji in vitro terhadap cacing dewasa adalah persentase kematian cacing akibat pemberian ekstrak obat herbal pada pengamatan setiap 2-4 jam selama 6 jam sampai semua cacing mati (Lismayanti 2002). Menurut Ratnawati et al. (2013), untuk mengetahui apakah cacing tersebut mati, paralisis, ataupun masih sehat, maka cacing disenggol dengan batang pengaduk. Jika 
diam saja maka dilakukan pengecekan dengan cara memasukkan cacing tersebut ke dalam air hangat atau dengan pemberian garam. Apabila cacing tidak bereaksi maka cacing tersebut dinyatakan mati, dan jika masih bergerak cacing tersebut hanya mengalami paralisis maka cacing yang mengalami paralisis dimasukkan kembali ke dalam perlakuan ekstrak dan cacing dikatakan mati apabila motilitasnya hilang dan warnanya memudar, tidak bergerak saat digoyang dengan kuat atau saat dicelupkan pada air hangat $40^{\circ} \mathrm{C}$ (Jiju et al. 2013; Deore et al. 2009).

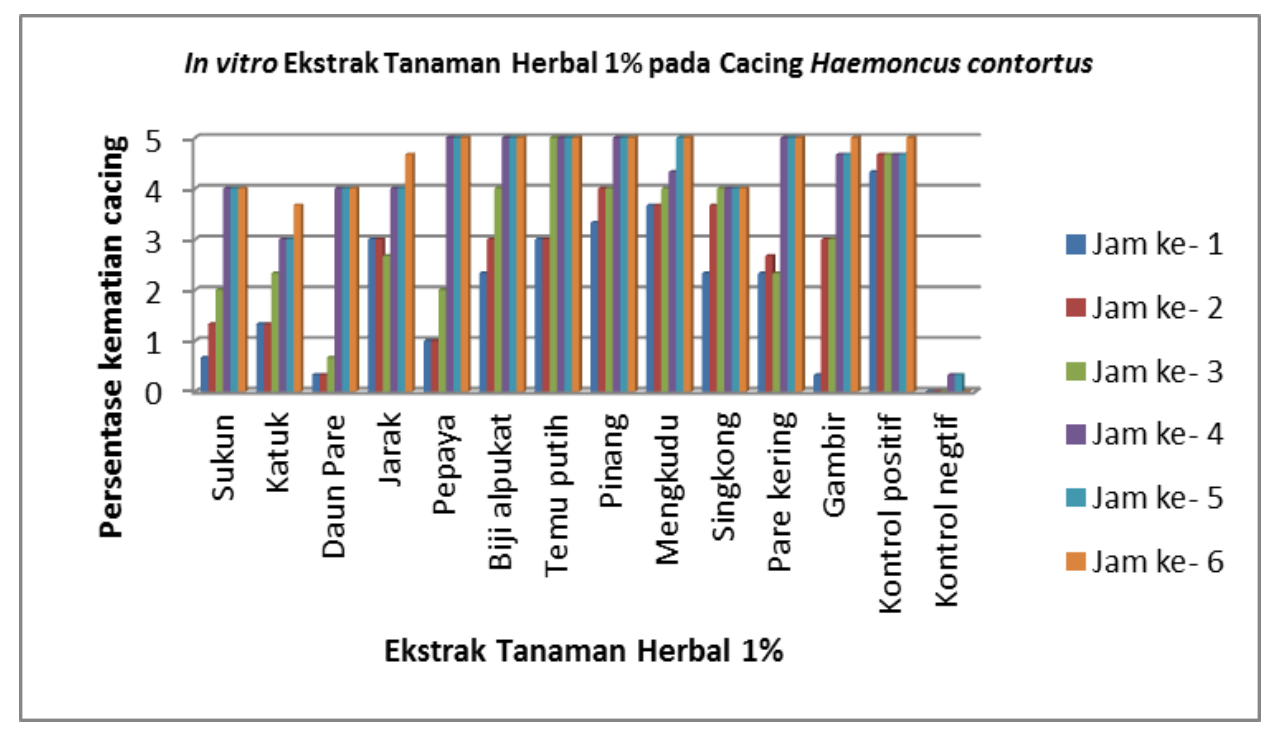

Keterangan:

Kontrol positif: Albendazole

Kontrol negatif: DMSO 1\%

Gambar 3. Hasil uji skrining 10 ekstrak tanaman herbal 1\% pada cacing $H$. contortus

Hasil yang diperoleh diamati dan dicatat waktu dan jumlah cacing yang mati setiap 2 jam (Agung 2012), sedangkan pada penelitian ini dilakukan pengamatan tiap jam hingga jam ke- 6 hal ini karena diasumsikan bahwa bahan aktif herbal merupakan bahan aktif yang cepat larut dan jangka waktu sampainya bahan kimia mulai dari tertelan hingga mencapai organ pencernaan khususnya abomasum kurang lebih 4 jam. Pengamatan dilakukan dibawah mikroskop stereoskopik berdasarkan persentase jumlah cacing yang mati dapat menunjukkan bahwa ekstrak herbal tersebut memiliki potensi sebagai vermisidal, yaitu temu putih, pinang, alpukat, pare, mengkudu.

Berdasarkan hasil pengamatan uji skrining diperoleh 5 tanaman herbal yang memiliki potensi paling baik sebagai anthelmintik, yaitu biji pare, buah mengkudu, biji alpukat, temu putih dan buah pinang. Hal ini didukung dengan adanya data hasil uji fitokimia pada keempat tanaman herbal tersebut yang menunjukkan bahwa keempat tanaman herbal tersebut memiliki kandungan alkaloid, saponin dan tanin yang bersifat anthelmintik. Kamaraj et al. (2011) serta Damayanti (2007) menyatakan bahwa pemilihan obat bahan alami sebagai antelmintik harus mengandung bahan aktif seperti saponin, tanin, flavonoid, dan alkaloid. Senyawa kimia tersebut memiliki aktivitas ovasidal, yang dapat mengikat telur cacing yang lapisan luarnya terdiri atas protein sehingga pembelahan sel di dalam telur tidak akan berlangsung pada akhirnya larva tidak 
terbentuk, membunuh dan memutus daur hidup cacing dewasa, larva maupun telur cacing (Tiwow et al. 2013).

Mekanisme kerja obat cacing nematoda efektif melawan beberapa spesies cacing nematoda gastrointestinal, baik telur, larva, maupun cacing dewasa dengan cara degenerasi sel intestin cacing sehingga penyerapan makanan untuk cacing menjadi terganggu dan lama-kelamaan cacing akan lemas kemudian mati (Muhibullah 2001). Obat cacing nematoda ekstrak tanaman herbal yang diuji efektivitasnya terhadap telur, larva dan cacing dewasa menggunakan parameter degenerasi sel intestin yang menghambat daya tetas telur (embrio buruk), membunuh larva (larva mati/tidak berkembang) dan membunuh cacing dewasa. Berdasarkan uji efektivitas skrining yang dilakuukan pada ekstrak tanaman herbal terhadap efektivitasnya sebagai obat cacing yang efektif dan efisien yang memiliki potensi secara ovisidal, larvasidal dan vermisidal ditunjukkan oleh beberapa ekstrak herbal, yaitu ekstrak herbal biji pare, buah mengkudu, biji alpukat, temu putih dan buah pinang. Mekanisme kerja anthelmintik dalam memberantas cacing adalah membunuh larva (larvasidal), cacing dewasa (vermisidal), serta dapat menghambat perkembangan telur cacing (ovisidal) (Ardana 2012).

\section{KESIMPULAN}

Hasil skrining ekstrak tanaman herbal etanol 96\%, menunjukkan bahwa secara berurutan 5 tanaman obat alami biji alpukat, rimpang temu putih, biji pare, buah mengkudu dan buah pinang berpotensi sebagai obat cacing nematoda pada ruminansia yang efektif dan efisien. Ekstrak biji alpukat 1\% menunjukkan memiliki aktivitas anthelmintik (ovisidal, larvasidal dan vermisidal) yang berpotensi digunakan sebagai obat cacing nematoda (Haemoncus contortus).

\section{SARAN}

Perlu dilakukan uji efektivitas dan toksisitas tanaman herbal sebagai obat cacing nematoda secara in vivo.

\section{UCAPAN TERIMA KASIH}

Penelitian ini terlaksana dengan anggaran penelitian dana DIPA BBLitvet tahun 2016. Ucapan terimakasih disampaikan kepada para Teknisi Litkayasa dari Laboratorium Parasitologi, BBLitvet (Bapak Zainal Kosasih, Bapak Farlin, Bapak Suharyanta, Bapak Sudrajad, Bapak Sukatma) yang telah membantu kegiatan penelitian di lapangan dan di laboratorium.

\section{DAFTAR PUSTAKA}

Ardana IBK, Bakta IM, Damriyasa IM. 2012. Peran ovisidal herbal serbuk biji pepaya matang dan albendazol terhadap daya berembrio telur cacing Ascaris suum secara In Vivo. J Kedokteran Hewan. 6:51-55.

Beriajaya, Priyanto D. 2004. Efektifitas serbuk daun nanas sebagai antelmintika pada sapi yang terinfeksi cacing nematoda saluran pencernaan. Prosiding Seminar Nasional Teknologi Peternakan dan Veteriner. Bogor (Indonesia): Pusat Penelitian dan Pengembangan Peternakan. hlm. 162-169. 
Beriajaya. 2005. Gastrointestinal nematode infections on sheep and goats in West Java, Indonesia. JITV. 10:293-304.

Damayanti. 2007. Uji daya anthelmintik ekstrak etanol daun pare (Momordica charantia L) terhadap cacing Ascaridia galli Schrank betina secara in vitro dan profil kromatografi lapis tipisnya [Internet]. [diaksed 29 Juni 2019]. Tersedia dari: http://digilib.ums.ac.id.

Deore SL, Khadabadi SS, Kamdi KS, Ingle VP, Kawalkar NG. Sawarkar PS, Patil UA, Vyas AJ. 2009. In vitro anthelmintic activity of Cassia tora. Int J Chem Tech Res. 1:177-179.

Dewi DA, Martindah E, Sawitri DH, Wardhana AH, Ekawasti F. 2017. Deteksi larva cacing nematoda sebelum dan sesudah pengobatan pada beberapa bangsa domba. Dalam: Puastuti W, Muharsini S, Inounu I, Tiesnamurti B, Kusumaningtyas E, Wina E, Herawati T, Hartati, Hutasoit R, penyunting. Prosiding Seminar Nasional Teknologi Peternakan dan Veteriner. Bogor (Indonesia): Pusat Penelitian dan Pengembangan Peternakan. hlm. 363-370. doi: 10.14334/Pros.Semnas.TPV-2017-p.363-370.

Dzulzila Z, Izranuddin MJ. 2004. Penggunaan teknologi terkini dalam ternakan kambing jermasia. Minda Keluaran Julai. Bilangan PP5250/7/2002.

Ekawasti F, Suhardono Sawitri DH, Dewi DA, Wardhana AH, Martindah E. 2017. Media penyimpanan telur, larva dan cacing nematode sebagai media uji in vitro. Dalam: Puastuti W, Muharsini S, Inounu I, Tiesnamurti B, Kusumaningtyas E, Wina E, Herawati T, Hartati, Hutasoit R, penyunting. Prosiding Seminar Nasional Teknologi Peternakan dan Veteriner. Bogor (Indonesia): Pusat Penelitian dan Pengembangan Peternakan. hlm. 695-703. doi: 10.14334/Pros.Semnas.TPV-2017-p.695-703.

Emery DL, Hunt PW, Jambre LFL. 2016. Haemonchus contortus: The then and now, and where to from here. Int J Parasitol. 46:755-769.

Garduño RG, de Gives PM, Hernández GT. 2013. Variability in the fecal egg count and the parasitic burden of hair sheep after grazing in nematode infected paddocks. Pesq Vet Bras. 33:469-475.

Jabbar A, Campbell AJD, Charles Ja, Gasser RB. 2013. First report of anthelmintic resistance in Haemonchus contortus in alpacas in Australia. Parasites Vectors. 6:243. doi: 10.1186/1756-3305-6-243.

Jackson F, Bartley D, Bartley Y, Kenyon F. 2009. Worm control in sheep in the future. Small Rumin Res. 86:40-45.

Jiju V., Megha Gorantla and Chamundeeswari D. 2013. Evaluation of anthelmintic activity of methanolic extract of Asystasia gangeticum. Int J Pharm Life Sci. 4:2727-2730.

Kamaraj C, Rahuman AA, Elango G, Bagavan A, Zahir AA. 2011. Anthelmintic activity of botanical extracts against sheep gastrointestinal nematodes, Haemonchus contortus. Parasitol Res. 109:37-45.

Lismayanti F. 2002. Uji pengaruh umur buah, cara sterilisasi, waktu simpan dan daya anthelmintik perasan nanas (Ananas comosus) terhadap cacing Ascaridia galli [Skripsi]. [Jakarta (Indonesia)]: Institut Sains dan Teknologi Nasional.

Mitchell GBB. 2007. Liver fluke. Dalam: Aitken ID, editor. Disease of sheep. 4th ed. London (UK): Blackwell. hlm 195-203.

Martindah E, Sawitri DH, Dewi DA, Wardhana AH, Ekawasti F. 2016. Faktor risiko dan tingkat resistensi cacing nematoda terhadap antelmintik pada sapi. Laporan Penelitian APBN 2016 [unpublish data].

Muhibullah. 2001. Efektivitas albendazole terhadap cacing nematoda pada ayam buras. Bogor (Indonesia): Institut Pertanian Bogor. 
Papadopoulos, Agis, Glinou GL, Papachristos DA. 2008. Developments in the utilisation of wind energy in Greece. Renewable Energy. 33:105-110. doi: 10.1016/j.renene.2007.03.005.

Papadopoulos DK, Skouloudaki K, Adachi Y, Samakovlis C, Gehring WJ. 2012. Dimer formation via the homeodomain is required for function and specificity of Sex combs reduced in Drosophila. Dev Biol. 367:78-89.

Prichard RK. 2001. Genetic variability following selection of Haemonchus contortus with anthelmintics. Trends Parasitol. 17:445-453.

Ratnawati D., Supriyati R., Ispamuji D. 2013. Aktivitas anthelmintik ekstrak tanaman putri malu (Mimosa pudica l) terhadap cacing gelang babi (Ascaris suum). Bengkulu (Indonesia): Fakultas MIPA, Universitas Bengkulu.

Razali, Azhari, Novita A., Ferasyi T.R., Ridwan, Munandar A. 2014. Potency of katuk leaf extracts and its suspension as anthelmintic against gastrointestinal nematodes in goat. $\mathrm{J}$ Kedokteran Hewan. 8.

Siregar DR. 2013. Analisis usaha pemelihraan ternak sapi potong program SMD [Skripsi]. [Padang (Indonesia)]: Universitas Andalas.

Surya R. 2014. Pengaruh pestisida alami dari ekstrak biji alpukat (Persea americana mill) terhadap tanaman sawi (Brassica sinensis l.) di Desa Paya Bedi Kec. Rantau Kab. Aceh Tamiang.

Tiwow D, Widdhi B, Novel SK. 2013. Uji efek antelmintik ekstrak etanol biji pinang (Areca catechu) terhadap cacing Ascaris lumbricoides dan Ascaridia galli secara in vitro. Pharmacon. 2:76-80.

Whitlock JH. 1948. Diagnosis of veterinary parasitism. Philadelphia (USA): Lea and Febiger. 